International Journal of Advanced Research in Engineering and Technology (IJARET)

Volume 11, Issue 7, July 2020, pp. 406-418, Article ID: IJARET 1107040

Available online athttp://iaeme.com/Home/issue/IJARET?Volume $=\overline{1} 1 \& \overline{\mathrm{I}} \mathrm{ssue}=7$

ISSN Print: 0976-6480 and ISSN Online: 0976-6499

DOI: 10.34218/IJARET.11.7.2020.040

(C) IAEME Publication

Scopus Indexed

\title{
A NUMERICAL STUDY ON THE INFLUENCE OF PILE HEAD CONNECTIONS ON PILED RAFT FOUNDATION UNDER VERTICAL AND STATIC HORIZONTAL LOADS
}

\author{
Uttam Kumar \\ Research Scholar, Applied Mechanics Department, SVNIT Surat, Surat, India \\ Dr. S A Vasanwala \\ Professor, Applied Mechanics Department, SVNIT Surat, Surat, India
}

\begin{abstract}
On the behalf of both rigid and hinged pile head connections, the piled raft foundation can be examined for its design function. A numerical study has been carried out on the piled raft subjected to uniform vertical load and static horizontal load. A constant spacing and a constant uniform length to diameter ratio of $3 \times 3$ pile group of piled raft models were adopted. Such three-dimensional finite element models were validated first and then the study of these models resting on cohesion less soil has been carried out. The connection to the rigid and hinged pile head with raft was considered. Additionally, the effect of raft-soil stiffness has been also implemented. The effect of raising the horizontal load on piled raft has been investigated. The horizontal load applied was varied from about 6.25 percent to 12 percent of the vertical load applied. Normalized axial force, bending moment and lateral displacement of piles was examined along its normalized depth. Load sharing percentage of the piled raft components was calculated and its behaviour change was established for horizontal and vertical loading conditions. It was found largely dependent upon the connectivity of the pile head.
\end{abstract}

Key words: Hinged pile head connection, Rigid pile head connection, Normalized lateral displacement, Normalized bending moment, Normalized axial forces, Load sharing percentage of raft.

Cite this Article: Uttam Kumar and Dr. S A Vasanwala, A Numerical Study on the Influence of Pile Head Connections on Piled Raft Foundation under Vertical and Static Horizontal Loads, International Journal of Advanced Research in Engineering and Technology, 11(7), 2020, pp. 406-418.

http://iaeme.com/Home/issue/IJARET?Volume $=11 \&$ Issue $=7$ 
A Numerical Study on the Influence of Pile Head Connections on Piled Raft Foundation under Vertical and Static Horizontal Loads

\section{INTRODUCTION}

Studies have shown that the piled raft can be used as an efficient and inexpensive alternative to high-rise buildings [1-3]. The study of piled raft foundation is therefore not limited to vertical loads alone, it also involves earthquake loads, wind loads, liquefaction operation, dynamic loads and other horizontal load systems. Pile loads and moments are essential factors for pile design under lateral load analysis of piled raft [4]. Horizontal loading sources may be lateral earth strain, slope movements, pile driving nearby foundation, near-foundation excavation, etc. The piled raft foundation is being investigated under lateral load and combined lateral and vertical load due to the rise in trend of performance-based design currently in the field of geotechnical engineering. In this case the connectivity of the pile head becomes an important key for the rational design of piled raft under horizontal load.

$3 \mathrm{D}$ finite elements modelling approach had been executed by authors to investigate lateral displacement, bending moments and axial forces on piles, when piled raft models were subjected to horizontal loading and vertical loading [5,6]. In addition, analytical methods were developed along with numerical analysis to evaluate the sectional forces of piles of piled raft during lateral load analysis $[7,8]$.

Moreover, the pile head connectivity with raft was modelled and analysed by the finite element modelling under Psudo-static horizontal loads on raft level [9,10]. It was reported that the piled raft's lateral load sharing response was different from that of the vertical load sharing response in which the raft shared less load than the piles due to the early mobilization of the raft's ultimate lateral resistance. This study also shown the effect of the pile rigidity on bending moment and axial forces on piles of piled raft along its length. Bending moment on piles in piled raft with hinged pile head interaction was reduced significantly and the similar observation was reported by the author during the experimental and analytical analysis on piled raft subjected to horizontal load and moment [11]. At another side, there was only minor influence of the pile head connection condition on the pile axial force of piled raft [12]. Raft relative stiffness was also important to reduce the horizontal displacement on applying horizontal load [13].

This numerical study aims to examine the effect of the rigid and hinged pile head connections on the piled raft while applying the uniform vertical load and horizontal static load on the raft. To investigate both the settlement and lateral displacement performance of piled raft models, the raft-soil stiffness ratio was altered with raft thickness. The influence of increasing the horizontal load on the raft level on the distribution of bending moment and lateral displacement on the piles along its depth was investigated. At first vertical load was applied, then horizontal load was added to raise its value from about 6.25 percent to 12 percent of the vertical load applied. In addition, the load sharing percentage of components of piled raft foundation was determined with the finite element analysis. The influence of raft rigidity and pile head connections were examined on the load sharing response in both the loading conditions. This study focused on investigating the significance of pile head connectivity as well as raft relative stiffness on piled raft foundation behaviour, which may largely helpful for the design and practice of the foundation system under both static horizontal and vertical loading conditions.

\section{NUMERICAL ANALYSIS}

The piled raft foundation numerical analysis was carried out using 3D finite-element analyses. The PLAXIS 3D Finite Element package was used. The 3D model included comprehensive soil and piled raft treatment which was described by 15 noded wedge elements. The piles were taken to have a diameter of $0.6 \mathrm{~m}(\mathrm{D})$ and length of $10 \mathrm{~m}\left(\mathrm{~L}_{\mathrm{p}}\right)$. Consideration was given 
to a square raft with a width $B$ of $8 \mathrm{~m}$ (thickness $0.5 \mathrm{~m}, 0.8 \mathrm{~m}$ and $1 \mathrm{~m}$ ). It was assumed that the mesh stood on a rigid layer, and it was presumed that the vertical boundaries at the left and right sides were allowed to move downward soil layers. The side boundary was extended from the edge of raft laterally about 10 times the raft width. Throughout the analysis, Figure 1 indicates the conditions of the model. The connectivity to the rigid and hinged pile head was modelled separately.

The uniform vertical charge was applied to each piled raft model. The horizontal static load was about $6.25 \%, 7.80 \%, 9.40 \%$ and $12 \%$ of the uniformly vertical load. Both vertical and horizontal forces were applied in different phases during finite element modelling. The piled raft models were to rest on cohesion less soil up to 2.5 times depth of a pile. For a $3 \times 3$ configuration category, the piles were uniformly spaced 4.5 times the diameter of a pile. As shown in figure 2 the static horizontal load was applied separately at raft level.

\section{MODEL PROPERTIES}

The raft and piles that were modelled as linear elastic, while the soil was modelled as hardening soil model. Table 1 depicted the material properties of cohesion less soil, raft and piles. The hardening soil model uses the hyperbolic stress-strain curve to monitor the dependence of the stress level. Plaxis 3D software adopted the reference stress for stiffness $(p$ ref) as $100 \mathrm{kN} / \mathrm{m}^{2}$. The secant stiffness, tangent stiffness and unloading / reloading stiffness and other properties of the hardened soil model in the study are shown in Table 1 . The hardening soil model description have been described in Plaxis 3D material manual [15]. During modelling, fine refinement was used for the mesh generation for relatively accurate result as far as possible.

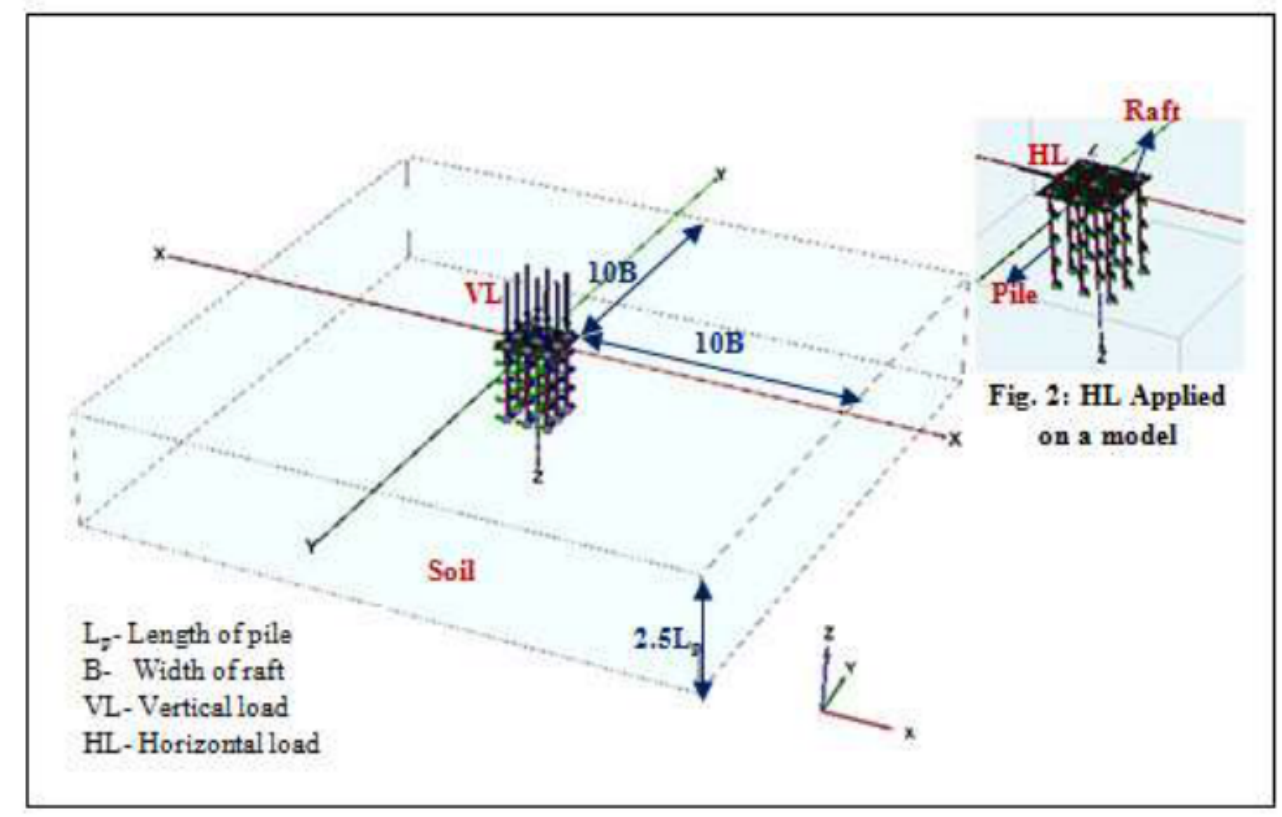

Figure 1 A Model showing boundary conditions, modelled elements and applied loads

Figure 2 HL Applied on a model 
A Numerical Study on the Influence of Pile Head Connections on Piled Raft Foundation under Vertical and Static Horizontal Loads

Table 1 Material properties for present numerical analysis

\begin{tabular}{|c|c|c|c|}
\hline Properties & Soil & Raft & Pile \\
\hline $\begin{array}{l}\text { Young's modulus of } \\
\text { elasticity (Mpa) }\end{array}$ & - & 30,000 & 30,000 \\
\hline Poission's ratio $(\boldsymbol{\vartheta})$ & 0.25 & 0.2 & 0.2 \\
\hline Total unit weight $\left(\mathrm{kN} / \mathrm{m}^{3}\right)$ & 16 & 25 & 25 \\
\hline $\begin{array}{l}\text { Angle of internal friction }(\boldsymbol{\varphi}) \\
\text { in degree }\end{array}$ & 32 & - & - \\
\hline $\begin{array}{l}\text { Secant stiffness modulus ( } \mathrm{E}_{50} \\
\text { ref } \text { ) in } \mathrm{kN} / \mathrm{m}^{2}\end{array}$ & 10000 & - & - \\
\hline $\begin{array}{l}\text { Tangent stiffness modulus } \\
\left(\mathrm{E}_{\text {oed }}{ }^{\text {ref }}\right) \text { in } \mathrm{kN} / \mathrm{m}^{2}\end{array}$ & 10000 & - & - \\
\hline $\begin{array}{l}\text { Unloading/reloading stiffness } \\
\text { modulus }\left(\mathrm{E}_{\mathrm{ur}} \text { ref }=3 \mathrm{E}_{\text {oed }} \text { ref }\right) \text { in } \\
\mathrm{kN} / \mathrm{m}^{2}\end{array}$ & 30000 & - & - \\
\hline $\begin{array}{l}\text { Power for stress level } \\
\text { dependency of stiffness (m) }\end{array}$ & 0.5 & - & - \\
\hline
\end{tabular}

Table 2 Material properties for the validation of numerical analysis (Choudhury et al., 2015)

\begin{tabular}{|c|c|c|c|}
\hline & Properties of sand & Properties of raft & Properties of piles \\
\hline $\begin{array}{l}\text { Young's modulus of } \\
\text { elasticity (MPa) }\end{array}$ & 28 & 70,000 & 70,000 \\
\hline Poission's ratio $(\boldsymbol{\vartheta})$ & 0.3 & 0.2 & 0.2 \\
\hline $\begin{array}{l}\text { Total unit weight } \\
\left(\mathrm{kN} / \mathrm{m}^{3}\right)\end{array}$ & 15.9 & 27 & 27 \\
\hline $\begin{array}{l}\text { Angle of internal } \\
\text { friction }(\varphi) \text { in degree }\end{array}$ & 40 & - & - \\
\hline $\begin{array}{l}\text { Confining stress } \\
\text { dependent stiffness } \\
\text { modulus } \mathrm{E}_{50}\left(\mathrm{kN} / \mathrm{m}^{2}\right)\end{array}$ & $\begin{array}{l}\text { As per equation } \\
\text { presented }[9,15]\end{array}$ & - & - \\
\hline $\begin{array}{l}\text { Reference stiffness } \\
\text { modulus }\left(\mathrm{E}_{50}{ }^{\text {ref }}\right) \\
\left(\mathrm{kN} / \mathrm{m}^{2}\right)\end{array}$ & 17000 & - & - \\
\hline
\end{tabular}

\section{VALIDATION OF FINITE ELEMENT MODELS}

The models of the three-dimensional finite elements were studied under both vertical and horizontal loading conditions. In PLAXIS 3D, referred to by the author [9], the square raft side $400 \mathrm{~mm}$ and thickness $40 \mathrm{~mm}$ with 4 embedded piles $40 \mathrm{~mm}$ in diameter and a uniform length of $0.6 \mathrm{~m}$ was modelled. At first the vertical load of $3.384 \mathrm{kN}$ was applied to top of the raft and then the horizontal static load of $1.92 \mathrm{kN}$ and $3.84 \mathrm{kN}$ was applied.

The author [9] adopted the material properties, as shown in table no. 2. The numerical model was built sideways up to 10 times the raft's width and found enough in size because at the boundary there was almost zero overlap of isobars near the foundation for the validation of present finite element models. The piled raft 's vertical load-settling curve with both pile head connections was shown in Figure 3. The normalized lateral displacement along the length of the pile was plotted and displayed in Figure No. 4. 


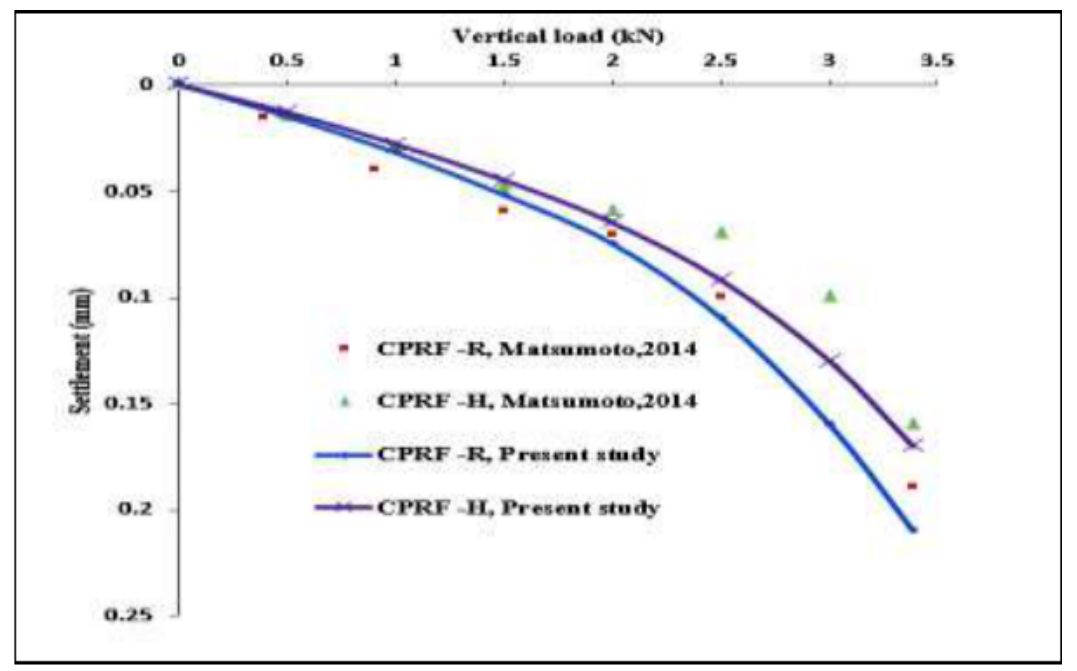

Figure 3 Load-settlement curve of rigid and hinged head connection of piled raft

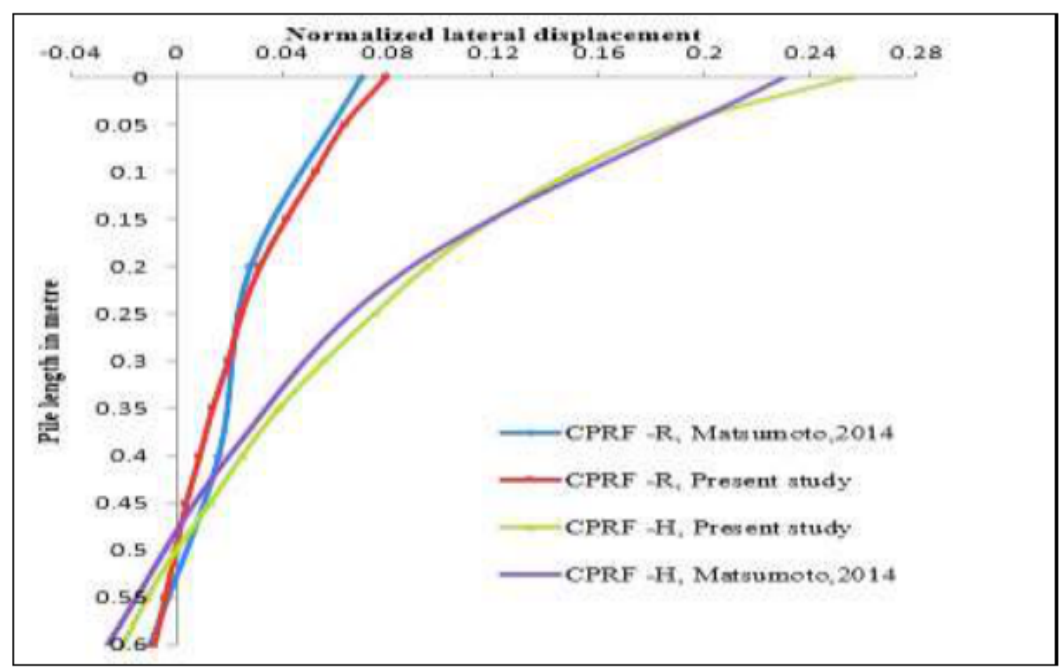

Figure 4 Normalized lateral displacement distribution along pile length

\section{RESULTS AND DISCUSSIONS}

The results have been discussed in terms of vertical uniform load on the top of raft and static horizontal charge on the raft level influence on piled raft. The rigidity of the raft-soil was measured using the equation referred to by the author [14]. The equation has been represented as equation 1, where $E_{r}$ and $E_{s}$ are modulus of elasticity of raft and soil respectively, $B, L$ and $\mathrm{t}_{\mathrm{r}}$ are width, length and thickness respectively, $\vartheta_{s}$ is soil's Poisson's ratio.

$$
K_{r s}=\frac{4}{3 \pi} \frac{E_{r}}{E_{s}} \frac{\left(1-\vartheta_{s}\right) B}{L} t_{r}^{3} / L^{3}
$$

The raft-soil stiffness was 3.87, 15.88 and 31 respectively, for various raft thicknesses, 0.5 $\mathrm{m}, 0.75 \mathrm{~m}$ and $1 \mathrm{~m}$. This relative stiffness of raft proposed the relative flexibility of piled raft.

The results of numerical simulations were addressed in the first sub section 5.1 because of the effect of uniform vertical loading on the piled raft simulations and the effect of horizontal loading on the piled raft models of interaction of both rigid and hinged pile heads with raft in the other sub section 5.2. The load sharing ratio of piled raft components on applying horizontal load along with vertical load have been also discussed in the separate section 5.3. 
A Numerical Study on the Influence of Pile Head Connections on Piled Raft Foundation under Vertical and Static Horizontal Loads

\subsection{Influence of Uniform Vertical Loading}

When applying uniform vertical load on raft, it was recorded that the normalized settlement of piled raft foundations was significantly reduced, when comparing raft settlement alone. Piles did in reality resist the settlement of the piled raft foundation structure. Figure 5 represents the normalized settlement of square raft and piled raft models with varying rigidity of raft-soil. The settlement was normalized with the foundation's vertical settlement separated by the square raft 's width. The sectional distance to the square raft 's width was established to get the normalized distance from the raft 's centre. The relative rigidity of raft was also effective in altering raft foundation settlement and differential settlement.

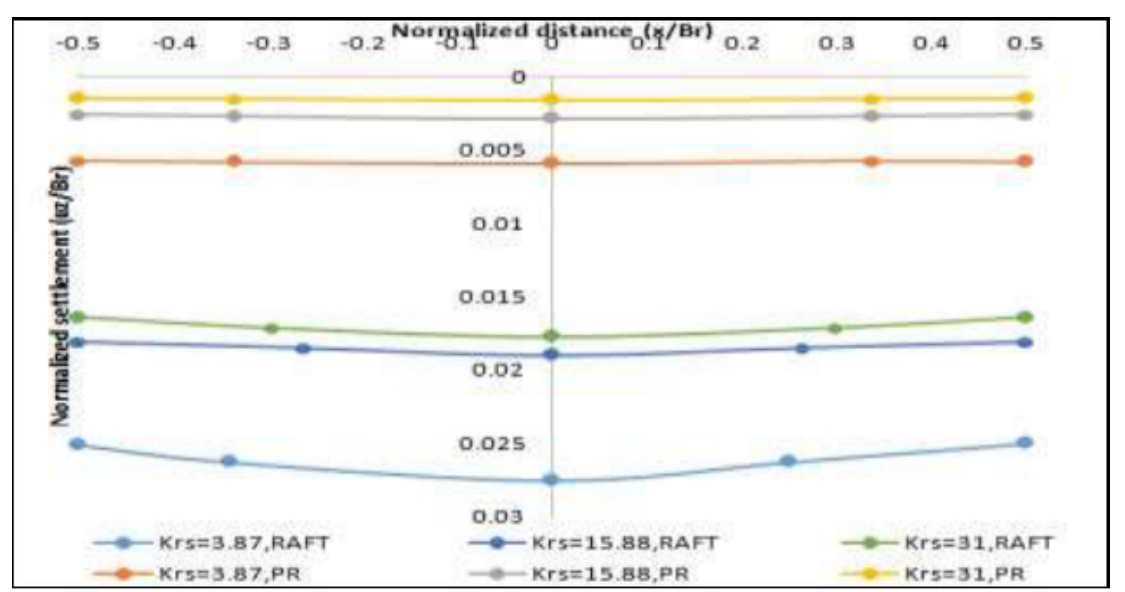

Figure 5 Normalized settlement of raft and piled raft of different relative stiffness

With the raft-soil stiffness ratio increased from 3.87 to 15.88 , the normalized settlement of both the raft and piled raft foundation decreased. In the case of piled raft, increasing the raftsoil stiffness ratio from 15.88 to 31 , the normalized settlement and normalized differential settlement have had negligible effect.

Figures 6 and 7 display the distribution of normalized axial force on piles of piled raft models along their corresponding depth with rigid and hinged coupling of the pile head, respectively. The normalized axial force of the piles was calculated as the axial force on a pile corresponding to the total vertical load applied to the raft. The depth of a pile was also normalized as the total depth of a pile to the corresponding depth. As the division of the related depth to the total depth of a pile, the depth of the pile was also normalised. There was maximum axial load found at the top near the pile head connection and significantly reduced at the bottom end of the pile along its length to about zero. The author had also mentioned the identical pattern for both of the pile head connections [9].

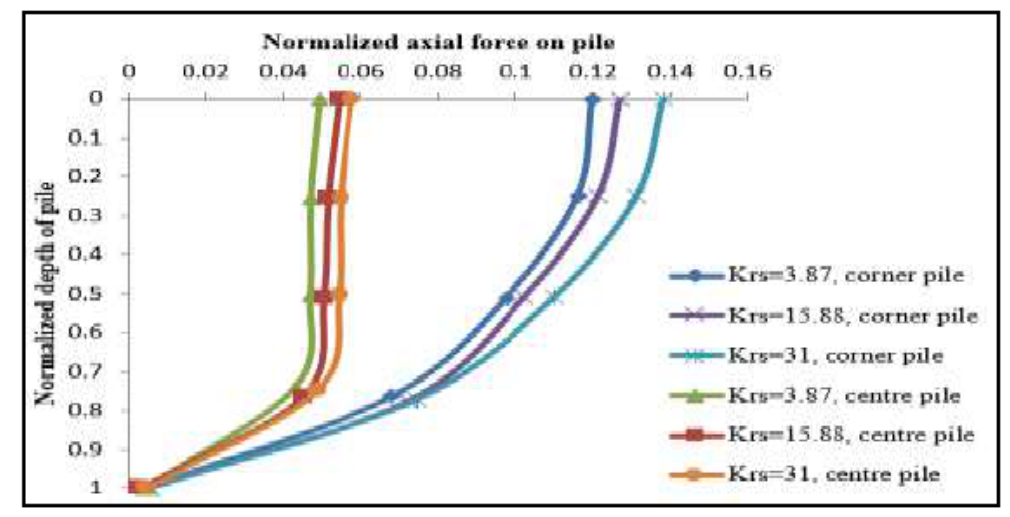

Figure 6 Normalized axial forces along the pile with rigid pile head connection 


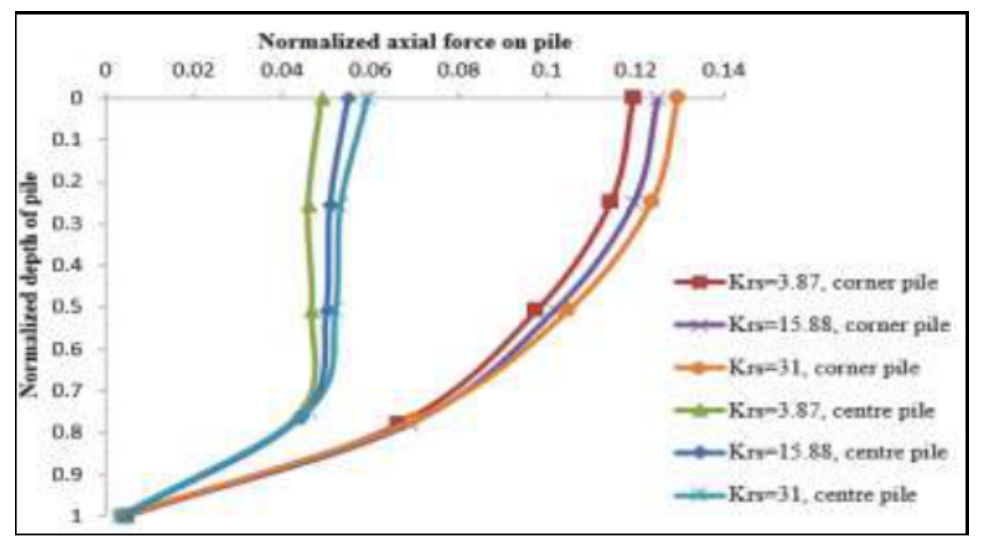

Figure 7 Normalized axial forces along the pile with hinged pile head connection

The corner pile was found to have achieved more axial load than the centre pile of $3 \times 3$ pile configuration of both rigid and hinged pile head connectivity. The normalized axial load of rigidly connected piles and the hinged connected piles of piled raft was found about unchanged. Hence, the effect of piled raft 's connection on axial forces of piles was reported negligible.

The raft-soil stiffness ratio has also been a key factor in investigating the behaviour of the piled raft. The piles of that foundation system obtained a higher value of normalized axial load for both the rigid and hinged coupling of the pile head, at a higher value of the relative stiffness of the raft of the piled raft structure.

\subsection{Influence of static horizontal loading on piled raft models with regard to changing the ratio of raft-soil stiffness and increasing horizontal load levels}

\subsubsection{Influence of static horizontal loading on raft models with respect to the change in raft-soil stiffness ratio}

In this section, the influence of relative raft rigidity of piled raft on the application of a constant horizontal load, 7.80 percent of the applied vertical load, was considered for discussion on the account of horizontal loading case. The important parameters to study were the lateral displacement and bending moment of piles of piled raft foundation having the rigid and hinged connected piles in case of static horizontal load along with application of vertical load. The piles were displaced together with raft at the top connection of the piled raft upon lateral load application along with vertical load.

The normalized displacement of piled raft along with normalized depth of a pile in the horizontal load direction for both the rigid and hinged pile head connections are shown in figure 8 and 9 respectively. The relative raft stiffness of piled raft was the variable parameters represented for normalized displacement as well as normalized bending moment. The lateral displacement, $\mathrm{u}$ was normalized by dividing a pile 's diameter, $\mathrm{D}$. The corresponding depth of the pile was also normalized after a division from the total depth of the pile. The normalized displacement was maximum near the top connection of pile. It subsequently decreased to about zero with an increase in normalized depth along its depth at the bottom end. The hinged connected piles displaced more than rigid connected piles. It was noted that the lateral displacement of piled raft was found to be reduced for both the pile head connections, with an increase in the relative stiffness of raft-soil.

The rigid connected piled raft displaced less than the hinged connected piled raft. It could be possible due to higher rigidity of rigidly connected piled raft than hinged connected piled raft. 
A Numerical Study on the Influence of Pile Head Connections on Piled Raft Foundation under Vertical and Static Horizontal Loads

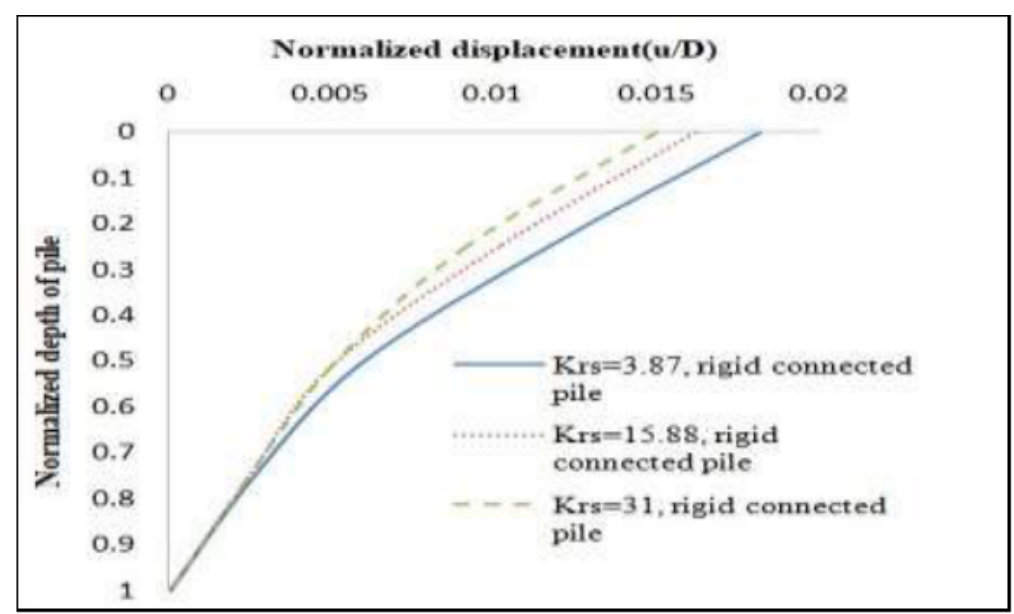

Figure 8 Lateral displacement of pile, rigidly connected to raft along the pile length

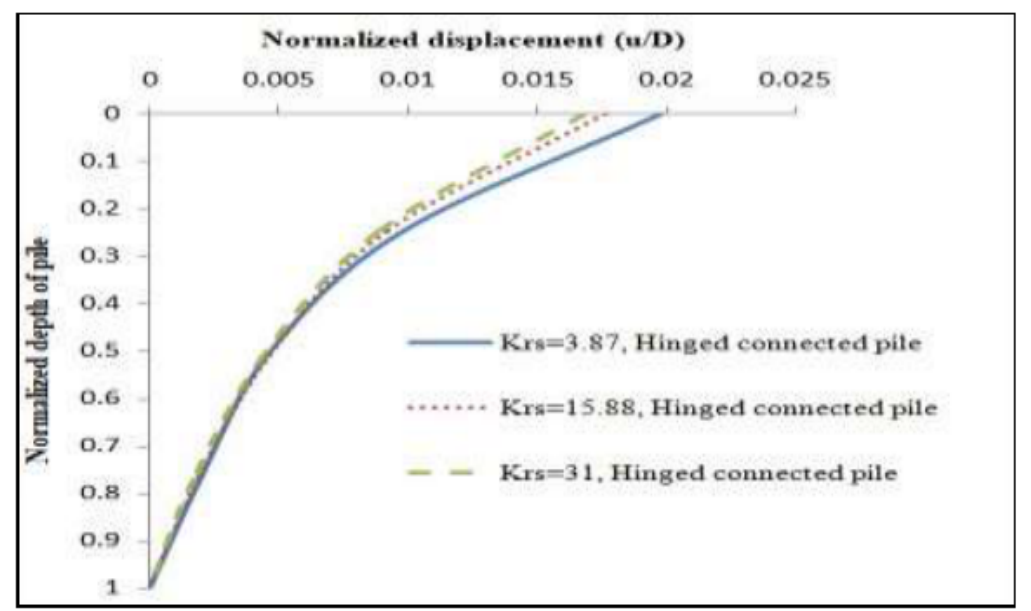

Figure 9 Lateral displacement of pile, hinged connected to raft along the pile length

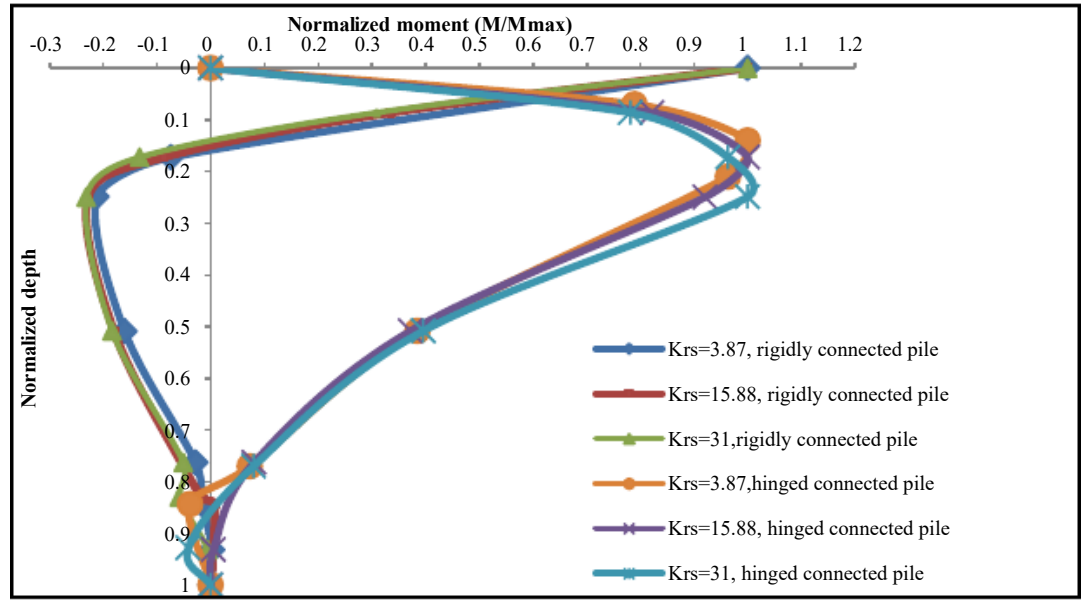

Figure 10 Bending moment of pile of piled raft with different relative stiffness

Figure 10 shows the pile's normalized bending moment along its normalized depth, measured as the maximum bending moment, $\mathrm{M}_{\max }$ to bending moment at the corresponding pile depth segment, M. It was observed that in the case of rigid pile head connections with raft, the normalized bending moment of the pile was found to be reduced from top to negative, and then to zero at the bottom end of the pile. In the case of a hinged pile head 
connection, the pile head had zero bending moment near the top and increased to the maximum along its normalized depth, and at the bottom end of the pile was reduced to zero. Similar observations of the bending moment distribution trend were presented [9].

\subsubsection{Influence of increasing static horizontal load on the piled raft models}

The static horizontal load level in the piled raft numerical models was varied by about 6.25 percent, 7.80 percent, 9.40 percent and 12 percent of the vertical load on the raft. Increasing the static horizontal load level on the piled raft in the horizontal direction of load at a constant raft-stiffness ratio of 15.88, normalized lateral displacement and normalized bending moment on the piles were plotted along its normalized depth to investigate the actions of hinged head connected and rigid head connected piled raft foundation. The normalized displacement of rigidly connected piled raft and hinged connected piled raft foundation models along the pile's normalized depth is shown in figures 11 and 12.

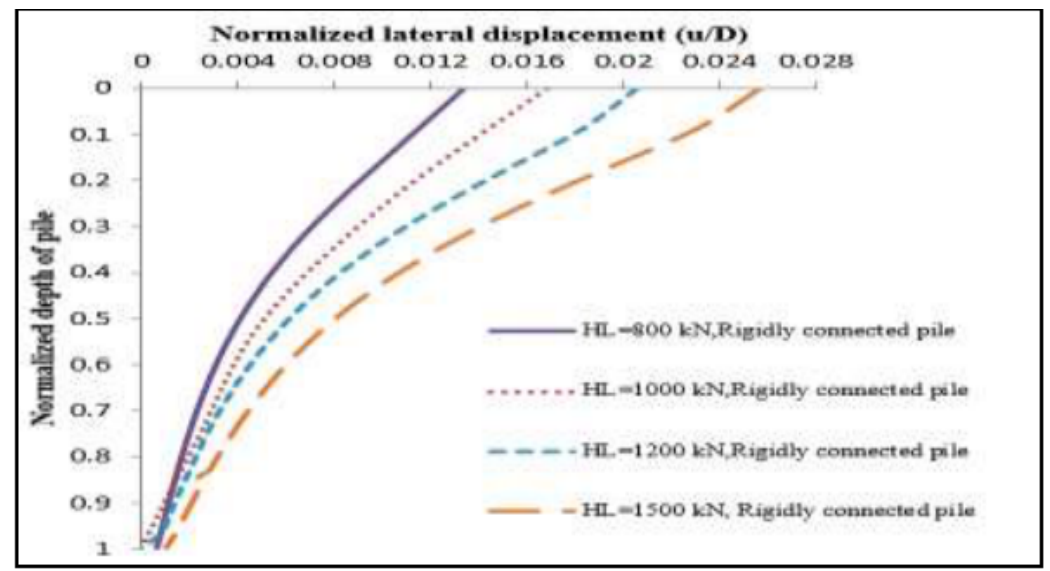

Figure 11 Normalized displacement of pile, rigidly connected to raft with the incremental horizontal load

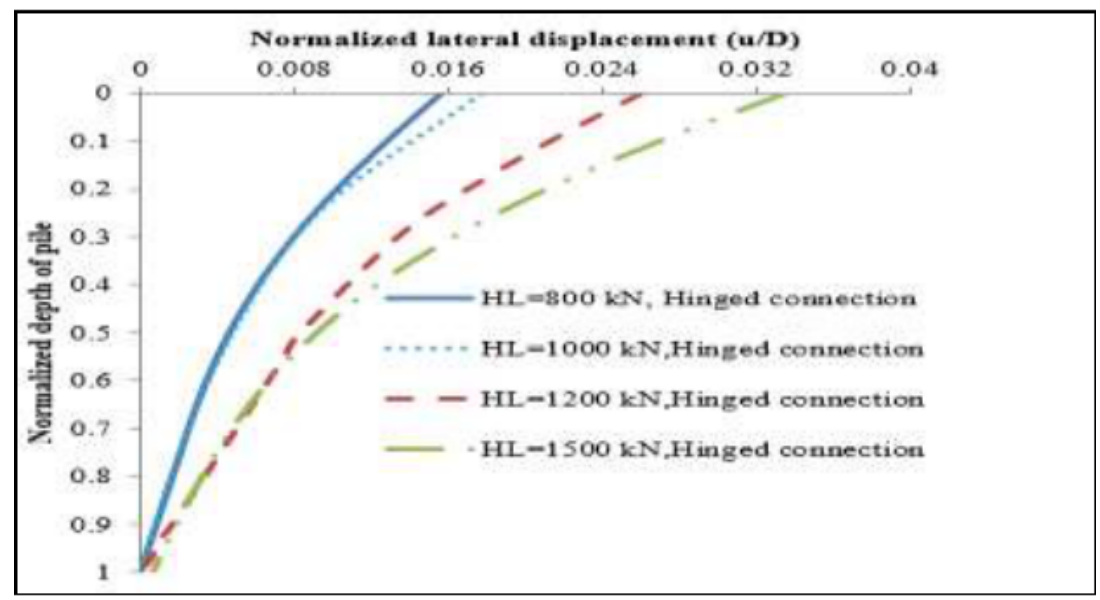

Figure 12 Normalized displacement of pile, hinged connected to raft with the incremental horizontal load

With an increase in the static horizontal load level on raft, the normalized displacement of the piles was found to be increased. The hinged connected pile, rising the horizontal load on raft, displaced more than a rigid connected pile of piled raft foundations.

Figures 13 and 14 characterize the normalized bending moment of the centre and corner pile of piled raft foundation of $3 \times 3$ pile configuration at a constant raft-stiffness ratio of 15.88 along the normalized pile depth respectively. The bending moment action of piles that had a 
rigid top connection and hinged top connection was different. Similar pattern of bending moment of piles of piled raft was also recorded when applying horizontal load on raft [10]. The hinged connected pile had no bending moment at the connection and the rigid connected pile had achieved maximum bending moment at top connection of pile. At the contact the hinged connected pile had no bending moment and the rigid connected pile had reached full bending moment at the top contact of the raft.

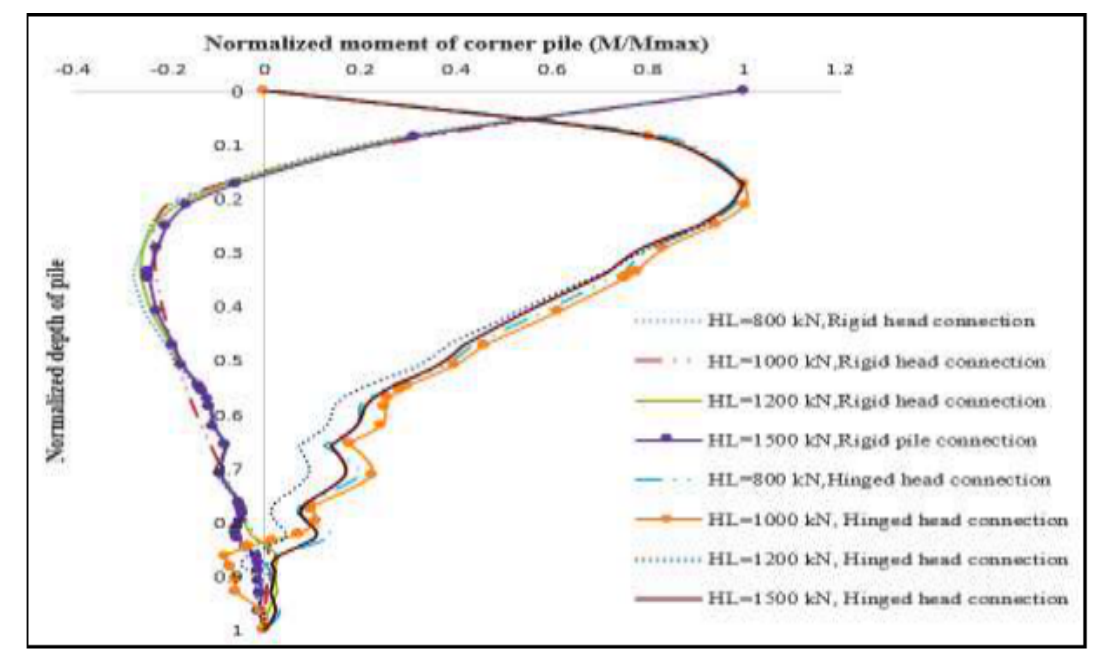

Figure 13 Normalized Bending moment of the corner pile along pile depth of piled raft

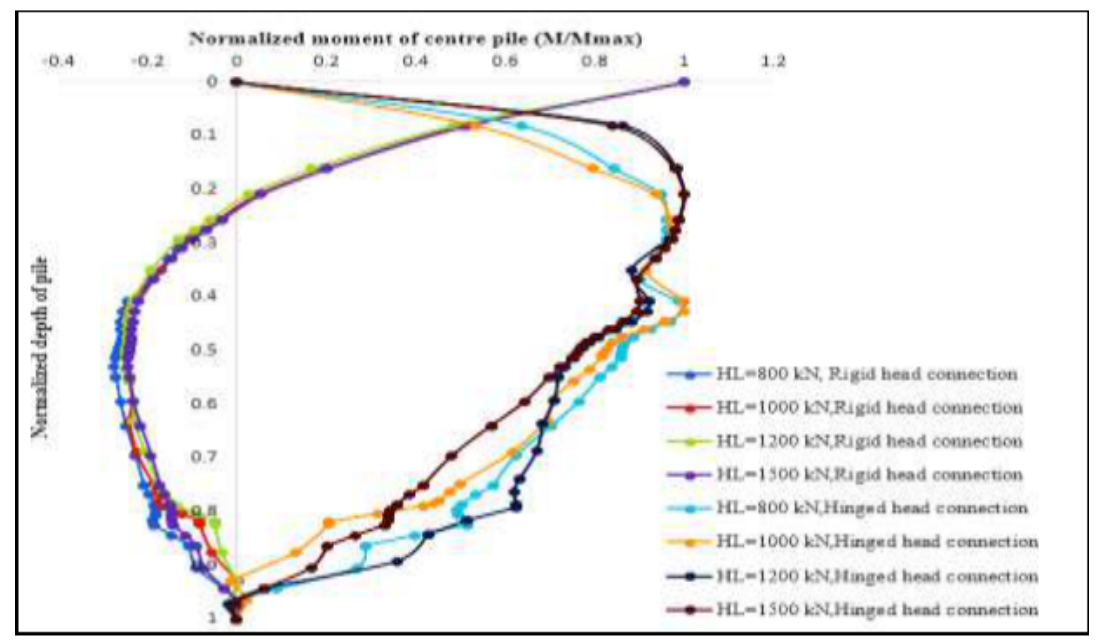

Figure 14 Normalized Bending moment of centre pile along pile depth of piled raft

\subsection{Load sharing response of piled raft model components of both hinged and rigid connectivity}

\subsubsection{Horizontal load sharing response of the raft}

The raft 's horizontal load distribution was determined by horizontal load carried by raft alone to the total horizontal load applied on piled raft. With the results of the Plaxis 3D program analysis, the horizontal load carried by the raft was determined by the total horizontal load imposed on piled raft minus the total horizontal load resisted by the piles. Similar process of estimation of horizontal load sharing proportions of piled raft components have been discussed [10]. Also, the author illustrated in a pictorial diagram of induced shear force of piles and raft base as well as interactions of piled raft components to estimate load sharing of piles and raft in finite element modelling [5]. 


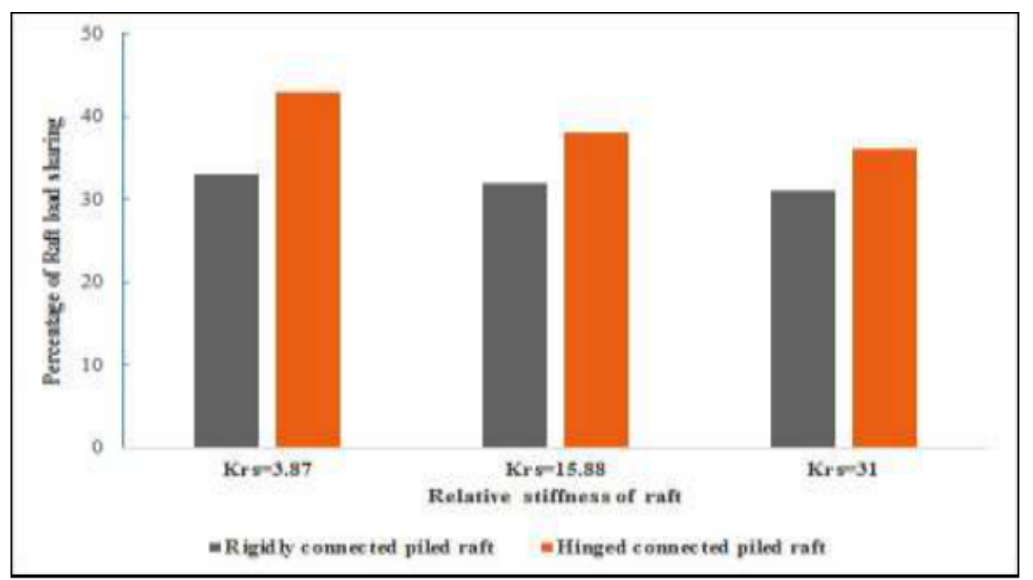

Figure 15 Load sharing percentage of raft with varying relative stiffness

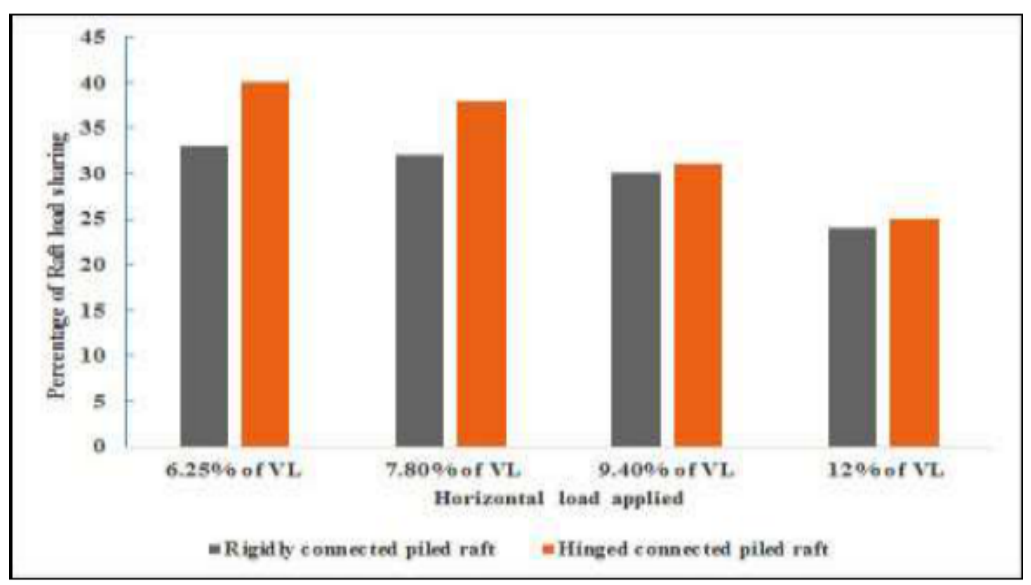

Figure 16 Load sharing percentage of raft with increasing the horizontal load

In the case of hinged connected piled raft, horizontal load sharing percentage of raft was more than rigidly connected piled raft. At a constant horizontal load of 7.80 percent of the vertical load applied, the raft shared approximately 31 percent to 33 percent of the total horizontal load applied for rigid pile head attachment and 35 percent to 42 percent of the total vertical load applied for hinged pile head attachment, decreasing the relative rigidity of the raft from 31 to 3.87 , as shown in figure 15. Figure 16 indicated that the raft's load sharing percentage was reduced by increasing the horizontal load value, and piles sharing percentage was increased on another side. The percentage of horizontal load sharing by raft was approximately $22 \%$ to $33 \%$ and approximately $23 \%$ to $41 \%$ for the rigidly connected and hinged piled raft, respectively, at a change of adopted horizontal load range in the study. It was because the shear force was very soon activated on raft base with an increase in horizontal load and afterwards piles started to resist the horizontal load more effectively than raft. Hence, the percentage of raft load sharing was found to be based on raft-soil stiffness ratio, pile head connections and increase in horizontal load on piled raft.

\subsubsection{Vertical load sharing response of the raft}

The vertical sharing of raft load was calculated by subtracting axial loads of the piles from the total vertical load applied to the top of the raft. Increasing the flexibility of raft with a decreasing relative stiffness value from 31 to 3.87 , it was observed that raft shared approximately 72 percent to 80 percent and approximately 68 percent to 72 percent of the total vertical load applied in the case of a rigid and hinged pile head connected piled raft. In fact, the percentage of raft load sharing with an increase in the adopted range of the raft's 
A Numerical Study on the Influence of Pile Head Connections on Piled Raft Foundation under Vertical and Static Horizontal Loads

relative stiffness was dropped due to the fact that flexible raft deformed more than rigid raft. Rigidly connected pile head of pile raft structure shared more percentage of vertical load than hinged piled raft structure.

\section{CONCLUSION}

Based on the results, the validity of the 3D finite element analysis model was evaluated and the behavior of piled rafts was examined under both uniform vertical loading and static horizontal load. From this study, the following conclusions can be drawn:

- The piles were found to be effective in reducing raft settlement and differential settlement of piled raft foundation with an increase in raft-soil rigidity adopted to a limit in the study.

- There was no major difference in axial forces regarding the application of uniform vertical load on both the rigid and hinged connected piles of piled raft foundation. The axial forces of both hinged and rigid connected piles were maximum at the top, then decreased down to the bottom along with depth of the pile. The axial forces on piles of piled raft were also dependent on raft-soil stiffness.

- An increase in the raft's relative stiffness from the adopted values of 3.87 to 31 , decrease was recorded in the lateral displacement of the piled raft at a constant horizontal load. Together with raft, the lateral displacement of piles was maximum at the top and it decreased along its depth until the bottom end of pile.

- At a constant horizontal load of about 7.80 percent of the applied vertical load in the adopted range of raft stiffness in the study, the rigid connected piles had experienced about 10 percent-12 percent lower lateral displacement than hinged connected piles of piled raft models near the pile head due to its greater stiffness than hinged connected piled raft.

With an increase in horizontal load at raft level from about 6.25 percent-12 percent, the piled raft with rigid connected piles displaced 8 percent -20 percent lower than the piled raft with hinged connected piles at a constant value of 15.88 of relative raft rigidity.

- In the case of rigidly connected piles of piled raft, the maximum positive moment of the piles was reached near the top and the maximum negative moment was found at the middle one-third section of the pile depth. Moreover, at the bottom end of the pile it decreased to about zero.

The bending moment at the top was zero in case of hinged connected piles of piled raft and the highest positive moment was reached at one-third portion of pile depth from the top. Furthermore, at the bottom end of the pile it decreased to about zero.

- The flexible raft deformed more than rigid raft and thus there was clear indication of decrease in raft load sharing percentage with an increase in relative rigidity of raft. The raft's load-sharing response was found to be different in both the applied vertical and horizontal load cases. In the vertical load case, the sharing of raft load was higher in the rigidly connected piled raft, while in the horizontal case the sharing of raft load was lower in the rigidly connected piled raft.

The pile head connection engaged a key role in load sharing between the raft and piles, where raft shared 31 percent to 42 percent of total horizontal load depending on the rigidity of the connection and in the range of raft rigidity adopted in the study. Additionally, depending on pile head connections and adopted range of horizontal load in the study, it was varied from about 22 percent to 41 percent. 
Hence, pile head connectivity is found to be an important factor affecting the lateral displacement, bending moment and load sharing response on piles of piled raft, which may be advancing the various design aspects of the piled raft foundation system.

\section{REFERENCES}

[1] Poulos, H.G., Bunce, G, 2008. Foundation design for the Burj Dubai: The world tallest building. In: Proceedings on the sixth international conference on case histories in geotechnical engineering, Arlinton. VA, pp 11-16.

[2] Poulos, H.G., Small, J.C, Chow, HSW, 2011. Piled raft foundation for tall buildings. Geotech Eng J SEAGS AGSSEA 42:78-84 13.

[3] Rabiei, M, Choobbasti, AJ, 2016. Piled raft design strategies for high rise buildings. Geotech Geol Eng 34(1):75-85.

[4] Poulous, H.G., 2001. Piled raft foundations: Design and applications, Geotechnique 51, No. 2, 95-113.

[5] Plaban, Deb, Sujit Kumar, Pal, 2019. Numerical analysis of piled raft foundation under combined vertical and lateral loading. Ocean Engineering, Volume 190, 15 October 2019, 106431.

[6] Nasr, E., Tamer, M. Sorour, 2016. 3-D Analysis of a Piled-Raft Foundation Subjected to Vertical and Lateral Loads Fourth Geo-China International Conference Fourth Geo-China International Conference. Shandong, China (C) American Society of Civil Engineers.

[7] Small, J. C., Zhang, H.H., 2002. Behavior of Piled Raft Foundations Under Lateral and Vertical Loading International journal of Geomechanics. Volume 2, Issue 1.

[8] J., Hamada, T., Tsuchiya, T., Tanikawa, K., Yamashita., 2015. Lateral Loading Tests on Piled Rafts and Simplified Method to Evaluate Sectional Forces of Piles Geotechnical Engineering Journal of the SEAGS \& AGSSEA Vol. 46 No.2. ISSN 0046-5828

[9] A, Kumar, D, Choudhary, R, Katzenbach, 2015. Behavior of combined pile -raft foundation under static and Pseudo-static conditions using PLAXIS 3D. 6th International conference on Earthquake Geotechnical Engineering, New Zealand.

[10] Ashutosh, Kumar, Deepankar, Choudhury, 2017. Load Sharing Mechanism of Combined PileRaft Foundation (CPRF) under Seismic Loads. Geotechnical Engineering Journal of the SEAGS \& AGSSEA Vol. 48 No. 3. ISSN 0046-5828

[11] Matsumoto, T, Fukumara, K, Kitiyodom, P, Horikoshi, K, Oki, A., 2004. Experimental and analytical modelling study on behavior of model piled raft in sand subjected to horizontal and moment loading. International Journal of Physical modelling in Geotechnics, 1-19.

[12] Matsumoto, T, Fujita, M, Mikami, H, Yaegashi, K, Arai, T, Kitiyodom, P., 2010. Load tests of piled raft models with different pile head connection conditions and their analyses. Soils and Foundations, 50(1):63-81.

[13] Horikoshi, K, Matsumoto, T, Hashizume, Y, Watanabe, T, Fukuyama, H. 2003. Performance of piled raft foundations subjected to static horizontal loading. International Journal of Physical Modelling in Geotechnics, 37-50.

[14] Jaeyeon, Cho, Jin-Hyung, Lee, Sangseom, Jeong, Jaehwan, Lee, 2012. The settlement behaviour of piled raft in clay soil, Ocean engineering 53, 153-163.

[15] Plaxis, BV.2013. Netherland User Manual, PLAXIS 3D. 